\title{
Pengaruh Suhu Ruang Simpan dan Perlakuan Pasca Penyimpanan terhadap Mutu dan Produktivitas Umbi Benih Bawang Merah (Allium cepa L. group Aggregatum)
}

\author{
The Effect of Storage Condition and After Storage on Quality and Productivity of \\ Seed Bulb of Shallot (Allium cepa L. Aggregatum group)
}

Alvita Sekar Sarjani ${ }^{1}$, Endah Retno Palupi ${ }^{2 *}$, M. Rahmad Suhartanto ${ }^{2,3}$, dan Y. Aris Purwanto ${ }^{3,4}$

Diterima 16 Agustus 2017/Disetujui 07 Februari 2018

\begin{abstract}
The fluctuative price of shallot in Indonesia is mainly due to discontinuous supply. Shallot is usually planted three times a year. Lack of supply occurs during July to October. Therefore, the produce need to be stored to ensure its availability during off season, not only for consumption but also as seed bulb for the following planting season. The research was aimed to maintain the quality of seed bulbs during twelve weeks storage and to evaluate productivity of the seed bulbs after storage. Shallot seed bulbs of Bima Brebes was used for the research that was devided into two steps. The first step was arranged in nested design, in which seed bulb was stored at $0{ }^{\circ} \mathrm{C}, 5^{\circ} \mathrm{C}, 10^{\circ} \mathrm{C}$ and ambient temperature nested into storage period i.e 0, 3, 6, 9 and 12 weeks with four replications. The second step was evaluation of productivity of the seed bulbs that was arranged in nested design. The seed bulbs, after being stored at diferent condition, was subjected to different acclimatization treatments i.e. gradual increase of temperatures for 3 days and direct change to ambient temperature for one day, to devernalize the seed bulbs and replicated our times. The results showed that the dormant period of shallot seed bulbs lasted for 8 weeks after harvest ( 6 week after storage) as indicated by germination and vigor index of $>90 \%$. The termination of dormancy coincided with a rise in GA, IAA and cytokines as well as ABA. Storing the seed bulbs for 3 months in $5{ }^{\circ} \mathrm{C}$ could maintain its viability and vigor $>90 \%$, with $9.8 \%$ of total damage and $15.6 \%$ of weight loss. The seed bulbs grew normally and produced $30.2 \mathrm{~g}$ of bulb per plant. The percentage of flowering plant of gradually acclimatized seed bulbs previously stored at $5{ }^{\circ} \mathrm{C}(10.3 \%)$ was not significantly different from those directly acclimatized at ambient temperature (12\%).
\end{abstract}

Keywords: ABA, cytokinin, dormancy, GA, weight loss

\begin{abstract}
ABSTRAK
Penyebab utama fluktuasi harga bawang merah di pasar adalah ketersediaan umbi bawang merah yang tidak stabil. Di daerah sentra produksi, bawang merah ditanam tiga kali dalam setahun. Bulan Juli sampai Oktober adalah periode hasil panen rendah. Penyimpanan umbi merupakan salah satu upaya untuk menjamin ketersediaannya di luar musim panen, tidak hanya untuk konsumsi tetapi juga memastikan ketersediaan umbi sebagai benih pada musim tanam selanjutnya. Penelitian ini bertujuan mempertahankan kualitas benih umbi selama 12 minggu disimpan dan mengevaluasi produktivitasnya setelah penyimpanan. Bahan yang digunakan adalah benih umbi bawang merah varietas Bima Brebes. Penelitian dibagi dalam dua tahap. Tahap pertama adalah penyimpanan benih umbi dirancang dalam nested design yang mana benih umbi disimpan pada suhu $0{ }^{\circ} \mathrm{C}, 5{ }^{\circ} \mathrm{C}, 10^{\circ} \mathrm{C}$ dan suhu ruang tersarang pada waktu penyimpanan yang terdiri atas $0,3,6,9$ dan 12 minggu dan diulang empat kali. Tahap kedua adalah evaluasi produktivitas benih umbi setelah disimpan dirancang dalam nested design. Umbi yang telah disimpan (12 minggu) pada masing-masing kondisi simpan diberi perlakuan aklimatisasi, yaitu suhu berjenjang (3 hari) dan suhu ruang langsung (1 hari), untuk
\end{abstract}

${ }^{1}$ Mahasiswa Program Studi Ilmu dan Teknologi Benih, Sekolah Pascasarjana, Institut Pertanian Bogor

J1. Meranti Kampus IPB Dramaga, Bogor 16680

${ }^{2}$ Departemen Agronomi dan Hortikultura, Institut Pertanian Bogor

J1. Meranti Kampus IPB Dramaga, Bogor 16680

${ }^{3}$ Pusat Kajian Hortikultura Tropika, Institut Pertanian Bogor,

Jl. Raya Pajajaran, Kampus IPB Baranangsiang, Bogor 16144

${ }^{4}$ Departemen Teknik Mesin dan Biosistem Institut Pertanian Bogor

Gedung Fateta, Kampus IPB Darmaga PO BOX 220, Bogor 16002

Email: erpalupi@yahoo.co.id (*Penulis korespondensi) 
mencegah pembungaan. Setiap perlakuan diulang sebanyak empat kali (ulangan tersarang pada aklimatisasi). Hasil penelitian menunjukkan bahwa benih umbi mengalami dormansi sampai 8 minggu setelah panen (6 minggu setelah simpan), ditandai dengan daya berkecambah dan indeks vigor di atas $90 \%$. Berakhirnya dormansi benih umbi bersamaan dengan peningkatan kandungan giberelin, auksin, dan sitokinin mengimbangi peningkatan asam absisat. Penyimpanan benih selama 12 minggu pada suhu $5{ }^{\circ} \mathrm{C}$ dapat mempertahankan viabilitas dan vigor di atas $90 \%$ dengan kerusakan (umbi bertunas, chilling injury, hampa atau busuk) sebesar 9.8\% dan susut bobot sebesar 15.6\%. Setelah disimpan selama 12 minggu benih dapat tumbuh normal dan memproduksi $30.2 \mathrm{~g}$ umbi per tanaman. Aklimatisasi suhu berjenjang umbi benih yang telah disimpan pada suhu $5^{\circ} \mathrm{C}$ menghasilkan persentase pembungaan (10.3\%) yang tidak berbeda nyata dengan aklimatisasi suhu ruang langsung (12\%).

Kata kunci: ABA, dormansi, GA, sitokinin, susut bobot

\section{PENDAHULUAN}

Bawang merah termasuk tanaman semusim dengan musim tanam pada bulan Oktober-Januari, Februari-April dan April-Juli (Setiapermas et al., 2013). Kelangkaan pasokan bawang merah umumnya terjadi sekitar bulan Maret (Kementerian Pertanian, 2014) karena sudah lewat musim panen, sementara permintaan tetap stabil sehingga menyebabkan kenaikan harga. Gejolak harga dapat dikendalikan dengan menjaga ketersediaan umbi baik umbi untuk konsumsi maupun benih umbi dengan cara menyediakan gudang penyimpanan. Dengan demikian, ketersediaan bawang merah konsumsi dan benih umbi lebih stabil. Basuki (2010) melaporkan bahwa petani melakukan penyimpanan benih umbi sampai musim berikutnya 3-3.5 bulan. Penyimpanan umumnya dilakukan pada suhu ruang dan menyebabkan susut bobot yang mencapai $40 \%$ sehingga menurunkan ketersediaan umbi. Menurut Mutia et al. (2014) penyimpanan umbi bawang merah selama 3 bulan pada suhu 25- 30 ${ }^{0} \mathrm{C}$ menyebabkan sekitar $21.75 \%$ busuk dan hampa. Penyimpanan pada suhu $5{ }^{\circ} \mathrm{C}$ dilakukan oleh Mardiana et al. (2016), menyebabkan umbi bertunas, berakar, busuk mencapai 7.58\% dan pembungaan mencapai $75 \%$. Penyimpanan umbi bawang merah pada suhu $10{ }^{\circ} \mathrm{C}$ menyebabkan umbi bertunas sebesar $43.6 \%$, umbi busuk $0.16 \%$ dan pembungaan sebesar $>10 \%$.

Penyimpanan umbi bawang merah sebelum tanam pada suhu rendah $\left( \pm 5^{\circ} \mathrm{C}\right)$ dapat menginduksi pembungaan (Ami et al., 2013). Pembungaan pada tanaman bawang merah umumnya tidak disukai oleh petani karena berpotensi mengurangi bobot umbi, sehingga menurunkan produktivitas. Efek vernalisasi pada bawang merah dapat dikurangi dengan perlakuan devernalisasi, yaitu dengan cara memaparkan umbi yang telah mengalami vernalisasi terhadap suhu tinggi $\left(>25{ }^{0} \mathrm{C}\right)$ dalam jangka waktu tertentu (Zenkteler et al., 2012). Perlakuan devernalisasi dalam penelitian ini dilakukan sebagai bagian dari proses aklimatisasi agar benih umbi yang telah disimpan pada suhu rendah beradaptasi terhadap suhu lingkungan tumbuh. Menurut Priyantono et al. (2016) aklimatisasi dapat dilakukan pada umbi bawang merah setelah penyimpanan suhu dingin. Perlakuan aklimatisasi dalam penelitian ini terdiri atas aklimatisasi suhu berjenjang dan aklimatisasi langsung pada suhu ruang yang bertujuan devernalisasi untuk mencegah pembungaan. Tujuan penelitian ini adalah memperoleh suhu ruang simpan terbaik dalam mempertahankan mutu benih umbi bawang merah selama 12 minggu dan mendapatkan informasi produktivitasnya setelah penyimpanan.

\section{BAHAN DAN METODE}

Penelitian ini dilaksanakan pada bulan September 2016 sampai Februari 2017. Penyimpanan benih umbi bawang merah dilakukan di Laboratorium Pusat Kajian Hortikultura Tropika (PKHT) IPB. Pengujian viabilitas, pertumbuhan dan produktivitas dilakukan di Lahan Percobaan Pasir Kuda IPB. Analisis kandungan zat pengatur tumbuh dilakukan di Laboratorium Balai Penelitian Tanaman Rempah dan Obat, Bogor. Benih umbi yang digunakan adalah bawang merah varietas Bima Brebes yang diperoleh dari CV. Agropundi Lestari Brebes berukuran sedang, 5-9 g, yang dipanen pada 
60 hari setelah tanam (HST) kemudian dikeringkan selama 10-15 hari (siap simpan).

\section{Penyimpanan Umbi Benih Bawang Merah}

Umbi benih bawang merah dipilah, dibersihkan kemudian dimasukkan ke dalam kemasan jaring plastik sesuai dengan satuan percobaan. Masing-masing kemasan disimpan dalam refrigerator dengan suhu sesuai perlakuan sebagai berikut: 1) $0{ }^{0} \mathrm{C}, \mathrm{RH} \pm$ $61.1 \%$, 2) $\left.5{ }^{\circ} \mathrm{C}, \mathrm{RH} \pm 62.8 \%, 3\right) 10{ }^{\circ} \mathrm{C}, \mathrm{RH} \pm$ $66.6 \%$, dan 4) suhu ruang $27{ }^{\circ} \mathrm{C}, \mathrm{RH} \pm 68 \%$.

Percobaan I. Pengaruh kondisi simpan terhadap mutu benih umbi bawang merah

Penelitian penyimpanan benih umbi dirancang dalam nested design dimana kondisi simpan $\left(0{ }^{\circ} \mathrm{C}, \mathrm{RH} \pm 61.1 \% ; 5{ }^{\circ} \mathrm{C}, \mathrm{RH} \pm 62.8 \%\right.$; $10{ }^{\circ} \mathrm{C}, \mathrm{RH} \pm 66.6 \%$; suhu ruang $27{ }^{\circ} \mathrm{C}, \mathrm{RH} \pm$ $68 \%$ ) tersarang pada lama penyimpanan yang terdisi atas 0, 3, 6, 9 dan 12 minggu. Perlakuan diulang empat kali. Pengamatan dilakukan setiap 3 minggu yang terdiri atas mutu fisiologis (daya tumbuh, indeks vigor, potensi tumbuh maksimum, kandungan GA, IAA, sitokinin dan $\mathrm{ABA}$ ), mutu fisik (susut bobot, umbi bertunas, chilling injury, dan umbi hampa) dan mutu patologis (busuk benih umbi). Data yang diperoleh dianalisis dengan menggunakan uji F. Apabila kondisi ruang simpan berpengaruh nyata, maka dilakukan analisis lanjut dengan menggunakan Duncan multiple range test (DMRT) pada taraf $\alpha=5 \%$.

Percobaan II. pertumbuhan, produktivitas dan pembungaan benih umbi setelah disimpan 12 minggu

Benih umbi yang telah disimpan 12 minggu pada masing-masing kondisi simpan kemudian diaklimatisasi dengan dua acara: $\mathrm{AB}$ =suhu berjenjang ( 3 hari) dan AR = langsung suhu ruang (1 hari) sebelum ditanam untuk evaluasi pertumbuhan dan produktivitasnya. Setiap perlakuan diulang sebanyak empat kali (total 16 satuan percobaan aklimatisasi suhu berjenjang dan 16 satuan percobaan langsung suhu ruang). Percobaan disusun dalam nested design, ulangan tersarang pada aklimatisasi. Pengamatan yang dilakukan terdiri atas pertumbuhan (tinggi tanaman, jumlah daun), produktivitas umbi (bobot umbi per rumpun) persentase tanaman berbunga. Data dianalisis dengan uji $\mathrm{F}$ dengan uji lanjut menggunakan Duncan multiple range test (DMRT) pada taraf $\alpha=5 \%$. Aklimatisasi suhu berjenjang, dilakukan dengan menaikkan suhu secara bertahap sesuai dengan suhu penyimpanan, sementara aklimatisasi suhu ruang langsung dilakukan dengan menyimpan benih umbi selama 1 hari pada suhu ruang kemudian ditanam (Tabel 1).

Tabel 1. Skema perlakuan aklimatisasi setelah penyimpanan pada masing-masing kondisi simpan

\begin{tabular}{|c|c|c|}
\hline $\begin{array}{l}\text { Kondisi } \\
\text { Simpan }\end{array}$ & Aklimatisasi & Keterangan \\
\hline \multicolumn{3}{|c|}{ Setelah disimpan selama 12 minggu benih umbi dikeluarkan dari refrigerator, kemudian } \\
\hline $\begin{array}{l}\text { Suhu } 0{ }^{\circ} \mathrm{C}, \\
\mathrm{RH} \pm 61.1 \%\end{array}$ & $\mathrm{AB}$ & $\begin{array}{l}\text { disimpan dalam ruang dengan suhu meningkat secara bertahap } 5{ }^{\circ} \mathrm{C} \text {, } \\
10^{\circ} \mathrm{C}, 15^{\circ} \mathrm{C}, 20^{\circ} \mathrm{C}, 25^{\circ} \mathrm{C} \text {, durasi masing-masing } 14.4 \text { jam }(3 \text { hari) }\end{array}$ \\
\hline $\begin{array}{l}\text { Suhu } 5^{\circ} \mathrm{C} \\
\mathrm{RH} \pm 62.8 \%\end{array}$ & $\mathrm{AB}$ & $\begin{array}{l}\text { disimpan dalam ruang dengan suhu meningkat secara bertahap } 10^{\circ} \mathrm{C} \text {, } \\
15^{\circ} \mathrm{C}, 20^{\circ} \mathrm{C}, 25^{\circ} \mathrm{C} \text {, durasi masing-masing } 18 \text { jam }(3 \text { hari }) . \\
\text { disimpan selama } 1 \text { hari pada suhu ruang kemudian ditanam. }\end{array}$ \\
\hline $\begin{array}{l}\text { Suhu } 10^{\circ} \mathrm{C}, \\
\mathrm{RH} \pm 66.6 \%\end{array}$ & $\mathrm{AB}$ & $\begin{array}{l}\text { disimpan dalam ruang dengan suhu meningkat secara bertahap } 15^{\circ} \mathrm{C} \text {, } \\
20^{\circ} \mathrm{C}, 25^{\circ} \mathrm{C} \text {, durasi masing-masing } 24 \text { jam }(3 \text { hari }) . \\
\text { disimpan selama } 1 \text { hari pada suhu ruang kemudian ditanam. }\end{array}$ \\
\hline $\begin{array}{l}\text { Suhu ruang, } \\
\mathrm{RH} \pm 68 \%\end{array}$ & $\begin{array}{l}\mathrm{AB} \\
\mathrm{AR}\end{array}$ & $\begin{array}{l}\text { disimpan selama } 3 \text { hari pada suhu ruang kemudian ditanam. } \\
\text { disimpan selama } 1 \text { hari pada suhu ruang kemudian ditanam. }\end{array}$ \\
\hline
\end{tabular}




\section{HASIL DAN PEMBAHASAN}

\section{Pengaruh Kondisi Simpan terhadap Mutu Fisiologis: Viabilitas, Vigor, Kandungan GA, IAA, Sitokinin dan ABA}

Pengujian viabilitas dan vigor benih umbi sebelum penyimpanan (15 hari setelah panen) menunjukkan bahwa daya tumbuh berkisar 24.5-32.5\%, potensi tumbuh maksimum (PTM) 27.5-33\% dan indeks vigor (IV) $20-26 \%$. Pada saat yang sama kandungan GA sebesar 25 ppm, IAA 44 ppm, sitokinin 18 ppm dan ABA 34 ppm (Gambar 1 dan 2). Data tersebut memberi indikasi bahwa benih umbi yang digunakan dalam penelitian ini dikategorikan masih dorman. Sharma et al. (2016) menyatakan bahwa dormansi dan pertumbuhan bawang merah bergantung pada jumlah hormon dan keterkaitan satu sama lain, seperti halnya saat tahap awal dormansi, aktivitas $\mathrm{ABA}$ endogen lebih aktif dan auksin relatif tidak aktif. Namun, saat memasuki tahap pertumbuhan, aktivitas auksin endogen lebih tinggi dan bertahan selama proses pertumbuhan umbi. Hal ini menunjukkan bahwa dormansi dan pertumbuhan umbi dipengaruhi oleh keseimbangan hormon endogen.

Setelah disimpan selama 3 minggu GA meningkat, $\mathrm{ABA}$ menurun, dan sitokinin tidak banyak berubah. Peningkatan GA dan penurunan ABA diduga menyebabkan terjadinya perubahan keseimbangan hormon. Pada saat yang bersamaan (3 MSS) viabilitas dan vigor benih umbi meningkat, daya tumbuh berkisar $64.5-72.5 \%$, indeks vigor $60.5-71.5 \%$ dan potensi tumbuh maksimum 64.5-72.5\% (Gambar 1). Perubahan keseimbangan hormon diduga menyebabkan peningkatan viabilitas dan vigor pada 3 MSS (5 minggu setelah panen), yang menjadi indikasi bahwa masa dormansi sudah hampir berakhir. Fenomena yang sama telah dilaporkan Ludford (1987) bahwa umbi bawang bombay setelah panen memiliki aktivitas ABA yang tinggi disertai dengan IAA, GA dan sitokinin yang rendah, pada kondisi ini umbi bawang bombay masih dalam masa dormansi. Perkecambahan umbi bawang bombay mulai terjadi saat keseimbangan hormon berubah, GA, IAA dan sitokinin perlahan meningkat dan ABA mulai menurun.
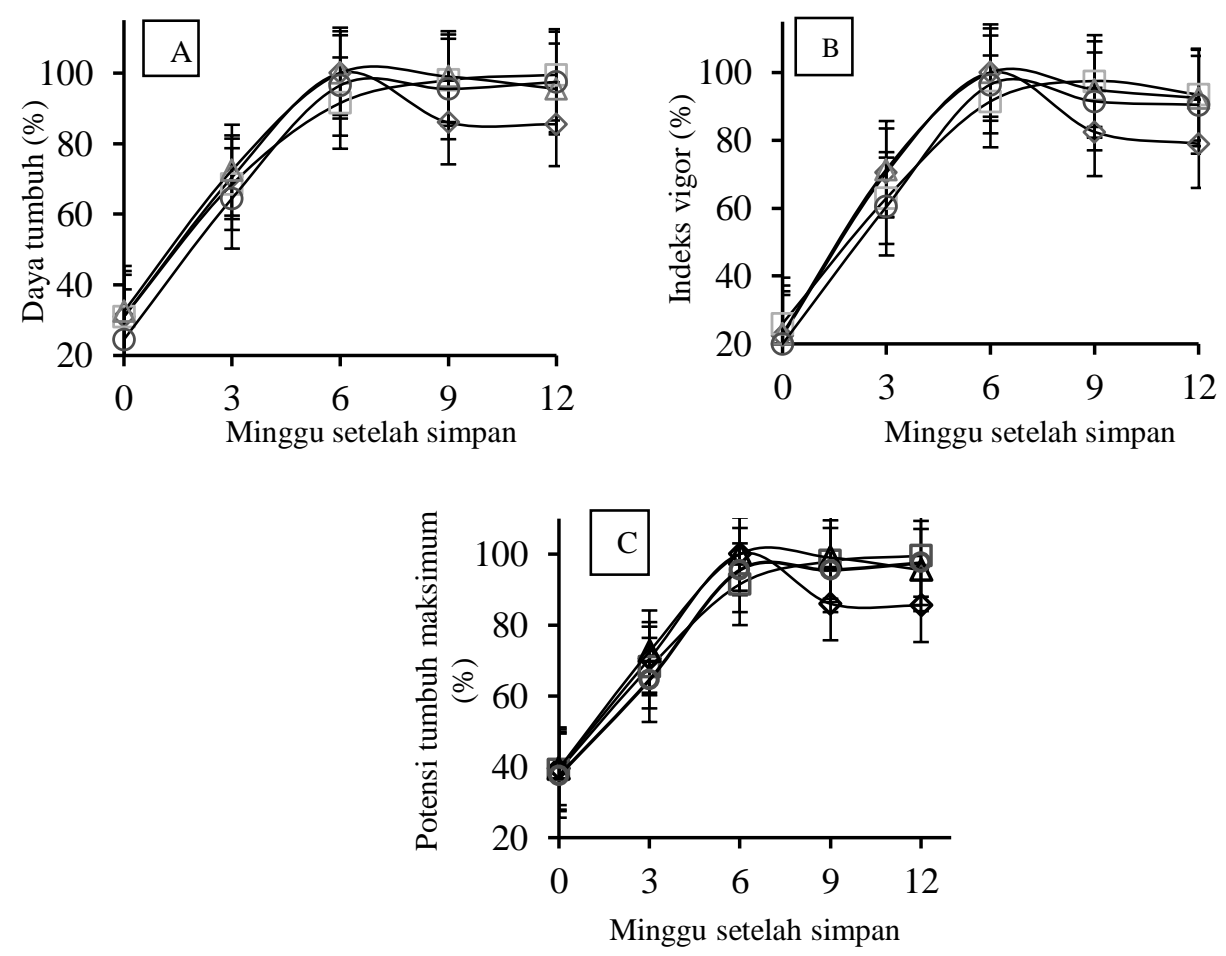

Gambar 1. Daya tumbuh (A), Indeks vigor (B) dan Potensi tumbuh maksimal (C) umbi benih bawang merah selama 12 minggu ruang bersuhu penyimpanan pada. $\neg 0{ }^{\circ} \mathrm{C}, \square-5^{\circ} \mathrm{C}, \triangle 10^{\circ} \mathrm{C}$, $\theta$ suhu ruang. 

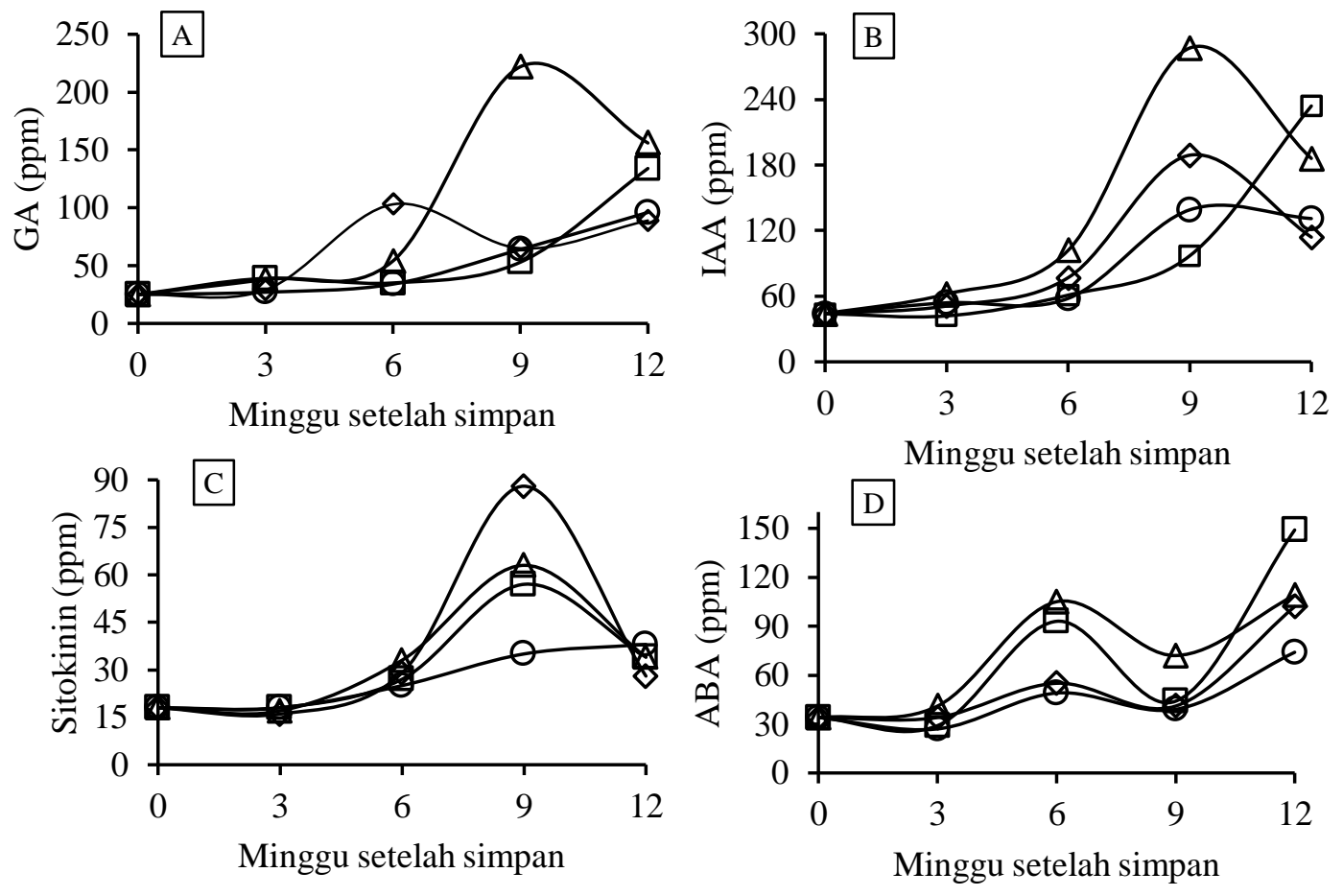

Gambar 2. Kandungan GA (A), IAA (B), sitokinin (C) dan ABA (D) umbi benih bawang merah selama 12 minggu penyimpanan, pada ruang bersuhu $\rightarrow 0{ }^{\circ} \mathrm{C}, \square 5{ }^{\circ} \mathrm{C}, \triangle 10{ }^{\circ} \mathrm{C}, \theta$ suhu ruang.

Daya tumbuh, indeks vigor dan potensi tumbuh maksimum benih umbi yang disimpan pada ruang bersuhu $0{ }^{\circ} \mathrm{C}, 5{ }^{\circ} \mathrm{C}, 10{ }^{\circ} \mathrm{C}$ dan suhu ruang mencapai maksimum sekitar $97 \%$ pada 6 MSS atau 8 minggu setelah panen, yang menunjukkan berakhirnya masa dormansi. Pada saat yang sama kandungan GA, IAA, sitokinin dan ABA meningkat, namun setelah penyimpanan 6 minggu kandungan ABA mulai menurun sedangkan GA, IAA dan sitokinin tetap meningkat. Hal ini menunjukkan terjadinya perubahan keseimbangan hormon. Keseimbangan hormon yang baru inilah yang diduga mendorong perkecambahan benih umbi sehingga viabilitas dan vigor mencapai maksimum. Wardani et al. (2012) melaporkan bahwa masa dormansi umbi bawang merah 4-5 minggu setelah panen. Data penelitian ini menunjukkan bahwa masa dormansi benih umbi bawang merah varietas Bima Brebes yang dipanen pada bulan September mempunyai masa dormansi selama 8 minggu setelah panen. Masa dormansi yang panjang memungkinkan umbi disimpan lama tanpa mengalami pertunasan, sehingga daya tumbuh tetap tinggi ketika digunakan sebagai bahan tanam atau dapat disimpan lama sebagai umbi konsumsi saat harga jual tinggi.
Daya tumbuh, indeks vigor dan potensi tumbuh maksimum benih umbi pada 9 dan 12 MSS tetap tinggi, sekitar 94\%. Pada saat itu kandungan GA, IAA dan sitokinin meningkat pesat (Gambar 2). Peningkatan kandungan ABA tidak berpengaruh terhadap daya tumbuh, indeks vigor dan potensi tumbuh maksimum. Viabilitas dan vigor tetap tinggi hingga $12 \mathrm{MSS}$ apabila disimpan pada suhu $5{ }^{\circ} \mathrm{C}, 10{ }^{\circ} \mathrm{C}$ dan suhu ruang, sementara benih umbi yang disimpan pada suhu $0{ }^{\circ} \mathrm{C}$ menunjukkan viabilitas dan vigor menurun walaupun daya tumbuh masih memenuhi standar minimum benih umbi bermutu. Penurunan viabilitas dan vigor terjadi bukan secara fisiologis namun secara fisik karena umbi mengalami chilling injury. Hong dan Ellis (1996); dan Manganaris et al. (2008) menyatakan bahwa chilling injury umumnya terjadi pada bahan tanam dengan kadar air tinggi dan disimpan pada suhu rendah. Air yang terkandung dalam bahan tanam membeku dan membentuk kristal es. Kristal es inilah yang merusak dinding sel sehingga ketika mencair bahan tanam kehilangan viabilitasnya. Secara umum, umbi bawang merah memiliki kadar air 81\% (Mardiana et al., 2016) yang relatif tinggi untuk disimpan pada suhu $0{ }^{\circ} \mathrm{C}$. Benih umbi yang disimpan pada suhu $0{ }^{\circ} \mathrm{C}$ 
mengalami chilling injury mencapai $1.3 \%$ (Tabel 2).

\section{Pengaruh Kondisi Simpan terhadap Mutu Fisik: Susut bobot, umbi bertunas dan chilling injury}

Susut bobot benih umbi mulai terjadi pada 3 MSS, terutama pada benih umbi yang disimpan pada ruang bersuhu $10{ }^{\circ} \mathrm{C}$ dan suhu ruang (Gambar 3), masing-masing mencapai $40.0 \%$ dan $42.7 \%$ pada 12 MSS. Tingginya susut bobot disebabkan oleh respirasi yang tinggi. Benkeblia et al. (2000) melaporkan bahwa bawang bombay yang disimpan pada suhu $4{ }^{0} \mathrm{C}$ mempunyai laju respirasi sebesar 0.88 mmole $\mathrm{kg}^{-1} \mathrm{~h}^{-1}$, pada $10{ }^{0} \mathrm{C}$ respirasi meningkat menjadi 0.91 mmole $\mathrm{kg}^{-1} \mathrm{~h}^{-1}$ dan pada $20{ }^{0} \mathrm{C}$ menjadi 0.93 mmole $\mathrm{kg}^{-1} \mathrm{~h}^{-1}$. Data ini menunjukkan bahwa semakin tinggi suhu penyimpanan maka laju respirasi meningkat, sehingga menyebabkan penyusutan bobot lebih cepat dibandingkan dengan suhu rendah.

Susut bobot yang mencapai $40-42 \%$ akan sangat merugikan bagi petani bawang terutama umbi untuk konsumsi, karena umbi tidak lagi segar bahkan hampa. Susut bobot yang lebih rendah pada ruang bersuhu $0{ }^{\circ} \mathrm{C}$ dan $5{ }^{\circ} \mathrm{C}$ menunjukkan bahwa pada suhu tersebut respirasi dapat ditekan. Bobot umbi berkurang sebesar 12-15\% selama simpan 12 minggu. Pengembangan teknologi penyimpanan masih perlu diperbaiki agar susut bobot umbi selama penyimpanan dapat ditekan.

Umbi yang disimpan pada suhu $10{ }^{\circ} \mathrm{C}$ dan suhu ruang mulai bertunas pada 3 MSS dan terus bertambah seiring berjalannya waktu. Di sisi lain, pada 3 MSS dormansi umbi mulai patah yang ditunjukkan oleh daya tumbuh dan perubahan kandungan GA dan auksin (Gambar 2). Kandungan GA dan auksin benih umbi sebelum simpan masing-masing sebesar 25 ppm dan 44 ppm meningkat menjadi 38 ppm dan 62 ppm pada 3 MSS. Perubahan kandungan hormon ini diduga memicu pertunasan benih umbi. Suhu simpan $10{ }^{\circ} \mathrm{C}$, RH $\pm 66.6 \%$ menyebabkan pertunasan $10.5 \%$ benih umbi pada 3 MSS. Umbi bertunas meningkat dengan semakin lama disimpan sehingga pada akhir penyimpanan (12 MSS) total umbi bertunas mencapai $48.7 \%$. Hasil penelitian ini sejalan dengan penelitian Sohany et al. (2016) yang menyatakan bahwa umbi bawang merah yang disimpan selama 60 hari $( \pm 8.5$ minggu $)$ pada suhu $13{ }^{\circ} \mathrm{C}$ mengalami pertunasan sebesar $68 \%$ sehingga menyebabkan penyusutan bobot umbi. Hasil penelitian ini menunjukkan bahwa suhu simpan 10-13 ${ }^{\circ} \mathrm{C}$ mampu mendorong pertumbuhan tunas.

Persentase pertunasan benih umbi yang disimpan pada suhu $10{ }^{\circ} \mathrm{C}$ mencapai puncaknya pada 12 MSS sebesar $48.7 \%$, sedangkan pada suhu ruang pertunasan maksimum sebesar $12.8 \%$, suhu $5{ }^{\circ} \mathrm{C}$ sebesar $3.5 \%$ dan suhu $0{ }^{\circ} \mathrm{C}$ sebesar 1.7\% (Tabel 2). Data ini menunjukkan bahwa suhu $0{ }^{\circ} \mathrm{C}$ dan $5{ }^{\circ} \mathrm{C}$ mampu menghambat pertunasan umbi bawang merah hingga akhir penyimpanan (12 minggu), seperti juga telah dilaporkan Mutia et al. (2014). Sementara itu umbi bawang bombay yang disimpan pada suhu $0-2{ }^{\circ} \mathrm{C}$ selama 6 bulan mengalami pertunasan 1 $6 \%$ (Adamicki, 2005).

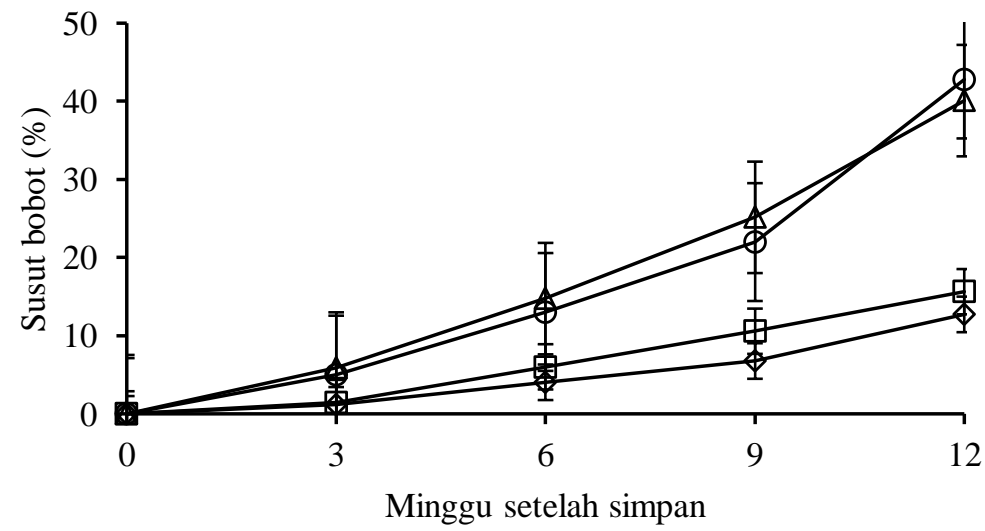

Gambar 3. Susut bobot umbi benih bawang merah pada ruang bersuhu $\neg 0{ }^{\circ} \mathrm{C}, \neg 5{ }^{\circ} \mathrm{C}, \triangle 10{ }^{\circ} \mathrm{C}$, $\theta$ suhu ruang selama 12 minggu penyimpanan. 
Chilling injury umumnya terjadi pada umbi yang disimpan pada suhu rendah $\left(\leq 5^{\circ} \mathrm{C}\right)$. Hasil pengamatan menunjukkan bahwa chilling injury lebih banyak terjadi pada benih umbi yang disimpan pada ruang bersuhu $5{ }^{0} \mathrm{C}$ daripada suhu $0{ }^{\circ} \mathrm{C}$ (Tabel 2). Pada ruang bersuhu $0{ }^{\circ} \mathrm{C}$ chilling injury mulai ditemukan pada 9 MSS sebesar $1.3 \%$ dan tidak bertambah sampai 12 MSS, sementara pada ruang bersuhu $5{ }^{\circ} \mathrm{C}$ chilling injury lebih cepat terjadi $(4.36 \%$ pada 6 MSS) dan lebih besar (6.3\% pada 12 MSS). Hal ini diduga fluktuasi suhu pada ruang bersuhu $5{ }^{0} \mathrm{C}$ mengakibatkan umbi dalam kondisi peralihan, kadang membeku kadang mencair, sehingga lebih banyak umbi yang rusak.

\section{Pengaruh Kondisi Simpan terhadap Mutu Patologis: Umbi Hampa dan Busuk}

Umbi hampa hanya ditemukan pada penyimpanan suhu ruang pada 6 MSS sebesar
$0.8 \%$, meningkat 9 MSS sebesar $1.6 \%$ dan pada akhir penyimpanan umbi hampa sebanyak $0.8 \%$ (Tabel 3). Suhu ruang yang tinggi (26.9 ${ }^{0} \mathrm{C}-29{ }^{\circ} \mathrm{C}$ ) meningkatkan laju penguapan umbi, yang menguras cadangan makanan dalam lapisan umbi. Semakin lama penyimpanan umbi pada suhu ruang semakin tinggi penyusutan bobot sehingga umbi menjadi hampa, mencapai $3.2 \%$ setelah disimpan selama 12 minggu. Umbi hampa tidak dapat digunakan sebagai benih karena kondisi fisik umbi yang rusak, tidak bernas dan lapisanlapisan umbi benih yang mengering. Penyimpanan pada ruang bersuhu rendah $\left(0^{\circ} \mathrm{C}\right.$, $5{ }^{\circ} \mathrm{C}, 10{ }^{\circ} \mathrm{C}$ ) dapat mencegah pembentukan umbi hampa, yang memberi indikasi bahwa suhu rendah mampu menjaga kesegaran umbi dan mutu benih umbi. Muthmainnah et al. (2014) menyatakan bahwa penyimpanan pada suhu rendah mampu mempertahankan kualitas buah karena respirasi yang cukup rendah.

Tabel 2. Persentase umbi bertunas dan chilling injury selama 12 minggu penyimpanan

\begin{tabular}{ccccccccc}
\hline \multirow{2}{*}{$\begin{array}{c}\text { Waktu } \\
\text { Penyimpanan } \\
\text { (Minggu) }\end{array}$} & \multicolumn{9}{c}{ Suhu $0{ }^{\circ} \mathrm{C}$} & \multicolumn{2}{c}{ Suhu $5{ }^{\circ} \mathrm{C}$} & Suhu $10{ }^{\circ} \mathrm{C}$ & \multicolumn{2}{c}{ Suhu Ruang } \\
& $\mathrm{RH} \pm 61.1 \%$ & \multicolumn{2}{c}{$\mathrm{RH} \pm 62.8 \%$} & $\mathrm{RH} \pm 66.6 \%$ & $\mathrm{RH} \pm 68 \%$ \\
\cline { 2 - 9 } & $\mathrm{UT}$ & $C I$ & $\mathrm{UT}$ & $C I$ & $\mathrm{UT}$ & $C I$ & $\mathrm{UT}$ & $C I$ \\
\hline 0 & $0 \mathrm{~g}$ & $0 \mathrm{~b}$ & $0 \mathrm{~g}$ & $0 \mathrm{~b}$ & $0 \mathrm{~g}$ & 0 & $0 \mathrm{~g}$ & 0 \\
3 & $0 \mathrm{~g}$ & $0 \mathrm{~b}$ & $0 \mathrm{~g}$ & $0 \mathrm{~b}$ & $10.5 \mathrm{~d}$ & 0 & $1.3 \mathrm{fg}$ & 0 \\
6 & $0 \mathrm{~g}$ & $0 \mathrm{~b}$ & $0 \mathrm{~g}$ & $4.3 \mathrm{a}$ & $25.5 \mathrm{c}$ & 0 & $3.5 \mathrm{ef}$ & 0 \\
9 & $0.6 \mathrm{~g}$ & $1.3 \mathrm{~b}$ & $1.5 \mathrm{fg}$ & $6.1 \mathrm{a}$ & $40.5 \mathrm{~b}$ & 0 & $5.5 \mathrm{e}$ & 0 \\
12 & $1.7 \mathrm{fg}$ & $1.3 \mathrm{~b}$ & $3.5 \mathrm{ef}$ & $6.3 \mathrm{a}$ & $48.7 \mathrm{a}$ & 0 & $12.8 \mathrm{~d}$ & 0 \\
\hline
\end{tabular}

Keterangan: UT $=$ umbi bertunas. $C I=$ chilling injury. Data telah ditransformasi menggunakan $\sqrt{\mathrm{x}}+0.5$.

Tabel 3. Persentase umbi hampa dan busuk selama 12 minggu penyimpanan

\begin{tabular}{ccccccccc}
\hline & \multicolumn{8}{c}{ Kondisi Simpan } \\
\cline { 2 - 8 } Waktu & Suhu $0{ }^{\circ} \mathrm{C}$ & \multicolumn{2}{c}{ Suhu $5{ }^{\circ} \mathrm{C}$} & \multicolumn{2}{c}{ Suhu $10^{\circ} \mathrm{C}$} & \multicolumn{2}{c}{ Suhu Ruang } \\
Penyimpanan & $\mathrm{RH} \pm 61.1 \%$ & $\mathrm{RH} \pm 62.8 \%$ & $\mathrm{RH} \pm 66.6 \%$ & $\mathrm{RH} \pm 68 \%$ \\
\cline { 2 - 9 } (Minggu) & Umbi & Umbi & Umbi & Umbi & Umbi & Umbi & Umbi & Umbi \\
& Hampa & Busuk & Hampa & Busuk & Hampa & Busuk & Hampa & Busuk \\
\hline 0 & 0 & 0 & 0 & 0 & 0 & 0 & $0 \mathrm{~b}$ & 0 \\
3 & 0 & 0 & 0 & 0 & 0 & 0 & $0 \mathrm{~b}$ & 0 \\
6 & 0 & 0 & 0 & 0 & 0 & 0 & $0.7 \mathrm{~b}$ & 0 \\
9 & 0 & 0 & 0 & 0 & 0 & 0 & $1.5 \mathrm{a}$ & 0 \\
12 & 0 & 0 & 0 & 0 & 0 & 0 & $3.2 \mathrm{a}$ & 0.1 \\
\hline
\end{tabular}


Tabel 4. Kerusakan umbi setelah penyimpanan pada kondisi simpan yang berbeda

\begin{tabular}{lcccc}
\hline \multicolumn{1}{c}{ Penurunan Mutu Benih } & Suhu $0{ }^{\circ} \mathrm{C}$ & Suhu $5{ }^{\circ} \mathrm{C}$ & Suhu $10^{0} \mathrm{C}$ & Suhu Ruang \\
Umbi Setelah Simpan & $\mathrm{RH} \pm 61.1 \%$ & $\mathrm{RH} \pm 62.8 \%$ & $\mathrm{RH} \pm 66.6 \%$ & $\mathrm{RH} \pm 68 \%$ \\
\hline Susut bobot & 13.3 & 16.3 & 47.2 & 50.4 \\
Umbi bertunas & 1.7 & 3.5 & 48.7 & 12.8 \\
Chilling injury & 1.3 & 6.3 & - & - \\
Umbi hampa & - & - & - & 3.2 \\
Umbi busuk & - & - & - & 0.1 \\
\hline Total & 16.3 & 26.1 & 95.9 & 66.5 \\
\hline
\end{tabular}

Busuk umbi hanya ditemukan pada umbi yang disimpan pada suhu ruang setelah 12 minggu sebesar $0.1 \%$ (Tabel 3). Busuk umbi umumnya disebabkan oleh mikroba yang terbawa benih umbi kemudian berkembang karena suhu penyimpanan yang relatif tinggi. Rasiukeviciute et al. (2016) melaporkan bahwa gejala pembusukan umbi pada penyimpanan biasanya dimulai saat di lapangan dan terbawa hingga penyimpanan. Menurut Kumar et al. (2015) Aspergillus niger adalah jamur yang umumnya menyerang umbi bawang saat dalam penyimpanan.

Persentase umbi busuk yang relatif rendah menunjukkan bahwa pemilahan umbi sebelum penyimpanan berhasil memisahkan umbi yang sehat dan yang membawa penyakit, oleh karena itu, pemilahan umbi yang akan digunakan sebagai benih umbi merupakan bagian yang sangat penting, terutama pemilihan umbi bebas dari penyakit. Umbi yang memiliki bercak hitam, berjamur dan lunak sebaiknya tidak digunakan sebagai benih umbi

Rekapitulasi kerusakan umbi (Tabel 4) menunjukkan bahwa kerusakan umbi dapat ditekan seminimal mungkin (16.3\%) dengan menyimpan umbi pada ruang bersuhu $0{ }^{\circ} \mathrm{C}$. Penyimpanan pada suhu $10{ }^{\circ} \mathrm{C}$ menyebabkan kerusakan umbi paling tinggi (95.9\%).

\section{Pertumbuhan, Produktivitas dan Pembungaan Benih Umbi}

Laju pertumbuhan benih umbi yang telah disimpan selama 12 minggu pada ruang bersuhu $0{ }^{0} \mathrm{C}, 5{ }^{0} \mathrm{C}$ kemudian diaklimatisasi (langsung atau suhu berjenjang) lebih tinggi dibandingkan benih umbi yang disimpan pada ruang bersuhu $10{ }^{\circ} \mathrm{C}$ dan suhu ruang dan diaklimatisasi (langsung atau suhu berjenjang)
(Tabel 5). Penelitian Tambunan et al. (2014) menunjukkan bahwa tinggi tanaman asal benih umbi Bima Brebes rata-rata $22.6 \mathrm{~cm}$, sementara tinggi tanaman bawang merah pada penelitian ini mencapai 32.2-41 cm. Data ini menunjukkan bahwa sebagian besar benih umbi yang disimpan selama 12 minggu dapat tumbuh dengan baik, kecuali umbi yang disimpan pada suhu ruang dengan aklimatisasi suhu ruang (AR). Tanaman yang lebih pendek dari benih umbi yang disimpan pada suhu ruang dengan aklimatisasi suhu ruang bukan disebabkan oleh proses aklimatisasi, akan tetapi disebabkan adanya serangan penyakit moler selama pertumbuhan di lapangan.

Tanaman dari benih umbi yang disimpan pada ruang bersuhu $10{ }^{\circ} \mathrm{C}$ dengan aklimatisasi berjenjang memiliki jumlah daun terbanyak (27.2 helai) dibandingkan dengan perlakuan lainnya (Tabel 5). Hal ini diduga disebabkan oleh pembentukan tunas samping pada umbi tersebut sehingga menghasilkan jumlah daun yang lebih banyak, bahkan lebih banyak dari hasil penelitian Septyma et al. (2015) yang menunjukkan rata-rata jumlah daun bawang merah Bima Brebes sebanyak 19.3 helai. Aklimatisasi suhu berjenjang pada umbi yang disimpan pada suhu $10 \quad{ }^{\circ} \mathrm{C}$ merupakan kesempatan umbi untuk menyesuaikan dengan lingkungan tumbuh secara bertahap, sehingga mampu mempertahankan pertumbuhannya dan menghasilkan jumlah daun yang tinggi. Sebaliknya, aklimatisasi langsung pada suhu ruang menghasilkan tanaman dengan jumlah daun lebih rendah (13.5). Penyimpanan umbi bawang merah pada suhu rendah $\left(5-10{ }^{0} \mathrm{C}\right)$ selama 3-4 minggu umumnya digunakan untuk menginduksi pembungaan dalam produksi benih botani (true seed of shallot/TSS) (Krontal et al., 2016; Rosliani et al., 2013). 
Tabel 5. Pertumbuhan, produktivitas dan persentase tanaman berbunga asal umbi yang telah disimpan 12 minggu

\begin{tabular}{cccccc}
\hline $\begin{array}{c}\text { Kondisi } \\
\text { Simpan }\end{array}$ & Aklimatisasi & $\begin{array}{c}\text { Tinggi } \\
\text { Tanaman }(\mathrm{cm})\end{array}$ & $\begin{array}{c}\text { Jumlah } \\
\text { Daun }\end{array}$ & $\begin{array}{c}\text { Bobot Umbi per } \\
\text { Rumpun }\end{array}$ & $\begin{array}{c}\text { Tanaman } \\
\text { Berbunga (\%) }\end{array}$ \\
\hline $0^{\circ} \mathrm{C}$ & $\mathrm{AB}$ & $39.1 \mathrm{ab}$ & $16.0 \mathrm{c}$ & $15.4 \mathrm{c}$ & $9.2 \mathrm{~b}$ \\
$\mathrm{RH} \pm 61.1 \%$ & $\mathrm{AR}$ & $39.0 \mathrm{ab}$ & $22.8 \mathrm{~b}$ & $28.7 \mathrm{a}$ & $8.8 \mathrm{~b}$ \\
$5^{\circ} \mathrm{C}$ & $\mathrm{AB}$ & $41.3 \mathrm{a}$ & $20.3 \mathrm{~b}$ & $27.9 \mathrm{a}$ & $10.2 \mathrm{~b}$ \\
$\mathrm{RH} \pm 62.8 \%$ & $\mathrm{AR}$ & $39.3 \mathrm{ab}$ & $20.6 \mathrm{~b}$ & $30.2 \mathrm{a}$ & $12.0 \mathrm{ab}$ \\
$10^{\circ} \mathrm{C}$ & $\mathrm{AB}$ & $33.2 \mathrm{c}$ & $27.2 \mathrm{a}$ & $15.7 \mathrm{c}$ & $16.0 \mathrm{a}$ \\
$\mathrm{RH} \pm 66.6 \%$ & $\mathrm{AR}$ & $32.2 \mathrm{c}$ & $13.5 \mathrm{c}$ & $19.4 \mathrm{bc}$ & $9.4 \mathrm{~b}$ \\
$\mathrm{Suhu}$ ruang & $\mathrm{AB}$ & $38.0 \mathrm{~b}$ & $23.1 \mathrm{~b}$ & $23.6 \mathrm{ab}$ & $0 \mathrm{c}$ \\
$\mathrm{RH} \pm 68 \%$ & $\mathrm{AR}$ & $15.5 \mathrm{~d}$ & $7.4 \mathrm{~d}$ & $5.7 \mathrm{~d}$ & $0 \mathrm{c}$ \\
\hline
\end{tabular}

Keterangan: AB: aklimatisasi suhu berjenjang. AR: aklimatisasi langsung suhu ruang

Umbi benih yang disimpan pada ruang bersuhu $5{ }^{0} \mathrm{C}$ baik yang diaklimatisasi suhu berjenjang maupun langsung suhu ruang menghasilkan umbi dengan bobot per rumpun yang tinggi setara dengan umbi yang disimpan pada suhu $0{ }^{\circ} \mathrm{C}$ dengan aklimatisasi suhu ruang langsung (Tabel 5). Bobot umbi yang dihasilkan tersebut tidak berbeda nyata dengan yang disimpan pada suhu ruang dengan aklimatisasi suhu ruang selama 3 hari. Hal ini memberi indikasi bahwa ruang penyimpanan bersuhu $5{ }^{\circ} \mathrm{C}$ lebih mampu mempertahankan kemampuan pertumbuhannya sehingga umbi dapat tumbuh di lapangan dan menghasilkan bobot per rumpun tertinggi.

Aklimatisasi baik suhu berjenjang maupun langsung pada suhu ruang tidak berhasil mencegah pembungaan. Benih umbi yang disimpan selama 12 minggu pada suhu rendah dengan dua cara aklimatisasi tetap menghasilkan tanaman berbunga, sebanyak 8.8-9.2\% dari benih umbi yang disimpan pada suhu $0{ }^{\circ} \mathrm{C}$, sebanyak $10.2-12 \%$ dari benih umbi yang disimpan pada suhu $5{ }^{\circ} \mathrm{C}$, dan sebanyak 9.4-16.0\% pada suhu $10{ }^{\circ} \mathrm{C}$ (Tabel 5). Hal ini diduga karena penyimpanan suhu rendah dalam jangka waktu 12 minggu menyebabkan primordia bunga yang terinisiasi melalui induksi oleh suhu rendah telah mengalami diferensiasi sehingga berkembang menjadi bunga. Niu et al. (2004) menyatakan bahwa perlakuan suhu tinggi selama 2 hari tidak menyebabkan terjadinya devernalisasi, namun paparan suhu tinggi selama 4 hari mampu menunda pembungaan pada Campanula sp. Di sisi lain persentase tanaman yang berbunga dalam penelitian ini tergolong rendah diduga karena waktu penyimpanan yang terlalu lama. Penyimpanan benih umbi pada suhu $5-10{ }^{\circ} \mathrm{C}$ selama 3-4 minggu menghasilkan pembungaan
$>85 \%$ di dataran tinggi (Rosliani et al., 2012), sekitar 30\%-43\% di dataran rendah (Rosliani et al., 2013; Kurniasari et al., 2017). Sementara penyimpanan 12 minggu pada suhu ruang tidak menghasilkan pembungaan sama sekali karena induksi pembungaan bawang merah tidak terjadi pada suhu ruang.

Pembungaan pada bawang merah sangat dihindari petani karena berpotensi menurunkan bobot umbi. Hasil pengamatan menunjukkan bahwa bobot umbi per rumpun tidak berkaitan dengan persentase tanaman berbunga. Hal ini menunjukkan bahwa penyimpanan benih umbi pada suhu rendah tetap menguntungkan karena jumlah tanaman berbunga yang rendah, dan mampu menekan kerusakan umbi.

\section{KESIMPULAN}

Masa dormansi umbi bawang merah varietas Bima Brebes adalah 8 minggu setelah panen. Penyimpanan benih umbi bawang merah varietas Bima Brebes pada suhu $0{ }^{\circ} \mathrm{C}$ $(\mathrm{RH} \pm 61.1 \%)$ dan suhu $5{ }^{\circ} \mathrm{C}(\mathrm{RH} \pm 62.8 \%)$, mampu mempertahankan mutu fisik dan fisiologis benih umbi hingga 12 minggu simpan. Penyimpanan pada suhu $0{ }^{0} \mathrm{C}$ dapat menekan kerusakan fisik pada tingkat yang paling rendah $(16.3 \%)$, diikuti dengan penyimpanan pada suhu $5{ }^{\circ} \mathrm{C}$ dengan kerusakan sebesar $26.1 \%$. penyimpanan pada suhu $10{ }^{\circ} \mathrm{C}$ menyebabkan kerusakan umbi yang sangat tinggi (95.9\%).

Benih umbi yang telah disimpan 12 minggu pada suhu rendah $\left(0{ }^{\circ} \mathrm{C}\right.$ dan $\left.5{ }^{\circ} \mathrm{C}\right)$ mampu tumbuh dan berproduksi normal dengan jumlah umbi per rumpun sebanyak 5-6 dan produktivitas per tanaman sebesar 15.2$30.2 \mathrm{~g}$ dengan umbi berukuran besar. 
Pembungaan pada benih umbi yang disimpan pada suhu rendah tergolong kecil, sebesar mencapai $8.8-10.2 \%$.

\section{DAFTAR PUSTAKA}

Adamicki, F. 2005. Effect of pre-harvest treatment and storage condition on quality and shelf-life of onion. Acta Hort. 688: 229-238.

Ami, E.J., M.T. Islam, A.M. Farooque. 2013. Effect vernalization on seed production of onion. Agriculture, Forestry and Fisheries. 2(6): 212-217.

Basuki, R.S. 2010. Sistem pengadaan dan distribusi benih bawang merah pada tingkat petani di kabupaten Brebes. J. Hort. 20(2): 186-195.

Benkeblia, N., N. Shiomi, M. Osaki. 2000. Respiratory parameters of onion bulbs (Allium cepa) during storage, effect of ionizing radiation and temperature. $\mathrm{J}$. Sci. Food Agric. 80: 1772-1778.

Hong, T.D., R.H. Ellis. 1996. A protocol to determine seed storage behaviour. IPGRI Tech. Bulletin No. 1. Int. Plant Genetic Resources Inst. Rome.

Kementerian Pertanian. 2014. Produksi dan kebutuhan konsumsi umbi bawang merah. http://hortikultura.pertanian.go. id. [23 Maret 2016].

Krontal, Y., R. Kamenetsky, H.D. Rabinowitch. 2016. Flowering physiology and some vegetative traits of short day shallot: a comparison with bulb onion. J. Hort. Sci. Biotechol. 75(1): 35-41.

Kumar, V., Neeraj, S. Sharma, N.A. Sagar. 2015. Post harvest management of fungal diseases in onion. Int. J. Curr. Microbiol. App. Sci. 4(6): 737-752.

Kurniasari, L., E.R. Palupi, Y. Hilman, R. Rosliani. 2017. Peningkatan produksi benih botani bawang merah (Allium cepa var. ascalonicum) di dataran rendah Subang melalui aplikasi BAP dan introduksi Apis cerena. J. Hort. 27(2): 201-208.

Ludford, P.M. 1995. Hormon Change During Storage. Netherland (Ntl):. Kluwer Academic Publisher.

Manganaris, G.A., A.R. Vicente, C.H. Crisoto, J.M. Labavitch. 2008. Cell wall modification in chilling-injured plum fruit (Prunus salicina). Postharvest Biology and Technology. 48: 77-83.

Mardiana, Y.A. Purwanto, L. Pujantoro, Sobir. 2016. Pengaruh penyimpanan suhu rendah benih bawang merah (Allium ascalonicum) terhadap pertumbuhan benih. J. Keteknikan Pertanian. 4(1): 67-74.

Muthmainnah, H., R. Poerwanto, D. Efendi. 2014. Perubahan warna kulit buah tiga varietas jeruk keprok dengan perlakuan degreening dan suhu penyimpanan. J. Hort. Indonesia. 5(1): 10-20.

Mutia, K.A., Y.A. Purwanto, L. Pujantoro. 2014. Perubahan kualitas bawang merah (Allium ascalonicum L.) selama penyimpanan pada tingkat kadar air dan suhu yang berbeda. J. Pascapanen. 11(2): 108-115.

Niu, G., R. Heins, A. Cameron, W. Carlson. 2004. Vernalization and devernalization of Campanula 'Birch Hybrid' and Leucanthemum xsuperbum 'Snow Cap'. Hort Science. 39(7): 1647-1649.

Priyantono, E., A.Y. Purwanto, Sobir. 2016. Penyimpanan dingin bawang merah (Allium ascalonicum L.) varietas Bima Brebes, Tajuk dan Bali Karet. J. Agrobased Industry. 33(1): 32-38.

Rasiukeviciute, N., S. Suproniene, A. Valiuskaite. 2016. Effective onion leaf fleck management and variability of storage pathogens. Open Life Sci. 11: 250-269.

Rosliani, R., E.R. Palupi, Y. Hilman. 2013. Penggunaan benzilaminopurin dan boron terhadap pembungaan, viabilitas serbuk sari, produksi, dan mutu benih bawang merah di dataran rendah. J. Hort. 23(4): 339-349. 
Pardede, E.S.B., Mariati, R. Sipayung. 2015. Pertumbuhan dan produksi tiga varietas bawang merah (Allium ascalonicum L.) pada pemberian beberapa jenih pupuk oraganik di tanah terkena abu vulkanik sinabung. J. Online Agroekoteknologi. 3(4): 1436-1446.

Setiapermas, N.M., E. Rohman, S. Basuki. 2013. Pengkajian peningkatan produktivitas bawang merah berdasarkan kesesuaian standar operasional prosedur di wilayah pengembangan di Kabupaten Brebes. Seminar nasional dengan tema Menggagas Kebangkitan Komoditas Unggulan Lokal Pertanian dan Kelautan; 2013 Juni; Madura, Indonesia. Madura Hal: 129-141.

Sharma, K., R.Y. Lee, S.W. Park, S.H. Nile, 2015. Importance of growth zat pengatur tumbuh endogenes and temperature for physiological regulation of dormancy and sprouting in onions. J. Food Reviews International. 32(3):233-255.

Sohany, M., U.K. Sarker, S. Mahomud. 2016. Physiological changes in red onion bulbs at different storage temperature. J. Engine and Technol. 4: 261-266.

Tambunan, A.W., R. Sipayung, E.F. Sitepu. 2014. Pertumbuhan dan produksi bawang merah (Allium ascalonicum L.) dengan pemberian pupuk hayati pada berbagai media tanam. J. Online Agroekoteknologi. 2(2): 825-836.

Zenkteler, E., S. Samardakiewicz, A. Kaluzewicz, M. Knaflewski. 2012. Effect of devernalizatio on the transition from vegetative to prefloral phase of the broccoli (Brassica oleracea var. italica cv. Fiesta) shoot meristem. Acta Agrobotanica. 65(1): 29-36. 